\title{
OPEN
}

Published online: 17 January 2020

\section{Author Correction: Increase in the Population of Patients with Neovascular Age-Related Macular Degeneration Who Underwent Long-Term Active Treatment}

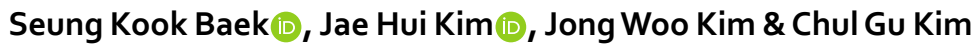 \\ Correction to: Scientific Reports https://doi.org/10.1038/s41598-019-49749-y, published online 13 September
} 2019

The original version of this Article contained an error in the Abstract.

"This retrospective, observational study included 18,165 patients who received anti-vascular endothelial growth factor injections (3,974 eyes).”

now reads:

“This retrospective, observational study included 3,380 patients who received anti-vascular endothelial growth factor injections (3,974 eyes)."

This error has now been corrected in the PDF and HTML versions of the Article.

(c) (i) Open Access This article is licensed under a Creative Commons Attribution 4.0 International cc) License, which permits use, sharing, adaptation, distribution and reproduction in any medium or format, as long as you give appropriate credit to the original author(s) and the source, provide a link to the Creative Commons license, and indicate if changes were made. The images or other third party material in this article are included in the article's Creative Commons license, unless indicated otherwise in a credit line to the material. If material is not included in the article's Creative Commons license and your intended use is not permitted by statutory regulation or exceeds the permitted use, you will need to obtain permission directly from the copyright holder. To view a copy of this license, visit http://creativecommons.org/licenses/by/4.0/.

(c) The Author(s) 2020 